Journal of Health Policy and Management (2019), 4(3): 150-160

https://doi.org/10.26911/thejhpm.2019.04.03.01

\title{
Does Health Center Have Contextual Effect on Midwife Performance? Multilevel Analysis Evidence from East Kalimantan, Indonesia
}

\author{
Latifah Nur Rahmadani'1), Uki Retno Budihastuti²), Eti Poncorini3) \\ 1)Masters Program in Public Health, Universitas Sebelas Maret \\ 2)Department of Obstetrics and Gynecology, Dr. Moewardi Hospital, Surakarta \\ 3)Faculty of Medicine, Universitas Sebelas Maret
}

\begin{abstract}
Background: The maternal mortality rate (MMR) which is still high has now become the priority in order to find its solution. Midwives play a very significant role in making efforts to reduce MMR through antenatal care (ANC) services. The performance of midwives directly influences the quality of service and health outcomes in the public health centers. The performance of midwives in ANC can be seen based on the coverage of $\mathrm{K} 1$ and $\mathrm{K} 4$. This study aimed to determine the contextual effect of public health centers and other factors that influence the performance of midwives in antenatal care services.

Subjects and Method: This study was conducted using observational analytic with cross sectional approach. It was done in 25 health centers in Samarinda, East Kalimantan in April-May 2019. The number of samples was 180 midwives selected using the total sampling technique. The dependent variable is the performance of the midwife. The independent variables include age, knowledge, tenure, training, workload, incentive, supervision, and motivation. The data were collected by questionnaire and analyzed by multilevel multiple logistic regression.

Results: Midwife performance was influenced by age $>45$ years $(b=-2.48 ; 95 \% \mathrm{CI}=-4.53$ to 4.34; $\mathrm{p}=0.018)$, good knowledge $(\mathrm{b}=1.35 ; 95 \% \mathrm{CI}=0.38$ to $2.31 ; \mathrm{p}=0.006)$, tenure $\geq 13$ years $(\mathrm{b}$ $=1.89 ; 95 \% \mathrm{CI}=-0.07$ to $3.86 ; \mathrm{p}=0.059)$, training $\geq 2(\mathrm{~b}=1.30 ; 95 \% \mathrm{CI}=0.29$ to $2.30 ; \mathrm{p}=0.011)$, heavy workload $(\mathrm{b}=-1.30 ; 95 \% \mathrm{CI}=-2.27$ to $-0.34 ; \mathrm{p}=0.008)$, incentive $(\mathrm{b}=1.74 ; 95 \% \mathrm{CI}=0.30$ to $3.18 ; \mathrm{p}=0.018)$, supervision $(\mathrm{b}=1.12 ; 95 \% \mathrm{CI}=0.19$ to $2.05 ; \mathrm{p}=0.017)$, and high motivation ( $\mathrm{b}$ $=1.42 ; 95 \% \mathrm{CI}=0.45$ to $2.38 ; \mathrm{p}=0.004)$. There was no contextual influence of public health center on the performance of midwives in antenatal care services (ICC $=<1 \%$ ).

Conclusion: Age, knowledge, tenure, training, workload, incentives, supervision, and motivation are associated with midwives performance. There is no contextual influence of public health centers on the performance of midwives.
\end{abstract}

Keywords: work performance, midwife, contextual effect, antenatal care

Correspondence:

Latifah Nur Rahmadani. Masters Program in Public Health, Universitas Sebelas Maret. Jl. Ir. Sutami 36 A, Surakarta 57126, Jawa Tengah. Email: latifahnr8@gmail.com. Mobile: 085250118907.

\section{BACKGROUND}

$\overline{\text { Maternal Mortality Rate (MMR) and Infant }}$ Mortality Rate (IMR) are the indicators of a nation's health. In 2015, around 303,000 women died during and after pregnancy and childbirth. Maternal mortality is caused by complications during and after pregnancy and childbirth including severe bleeding, infection, preeclampsia, and eclampsia, and complications from labor (WHO, 2018).

MMR in Indonesia currently has not reached the SDGs target for 2030 of 70 per 100,000 live births. The results of the 2015 Population Survey (SUPAS) reported that MMR in Indonesia amounts to 305 maternal deaths per 100,000 live births. The high level of MMR in Indonesia has made the 
government make efforts to reduce it as a priority program in health development (Marfu'ah et al., 2016). The number of MMR in East Kalimantan Province in 2016 was 100 per 100,000 live births. Meanwhile, MMR in Samarinda City has increased from 2016 by 40 per 100,00o live births to 92 per 100,000 live births in 2017 (Samarinda City Health Office, 2018).

Public health center is a governmental functional health organization that carries out comprehensive, integrated, fair, acceptable and affordable health efforts (Wanma et al., 2018). Public health centers require highly qualified health professionals to improve the public health (Bekru et al., 2017). One of its programs is Maternal and Child Health.

Midwives play an important role in reducing maternal and neonatal morbidity and mortality (Bekru et al., 2017). An effort that can be made in reducing $M M R$ and IMR is through antenatal care (ANC) services. ANC is health care carried out by skilled midwives to mothers during pregnancy to monitor maternal and infant health (Douglas et al., 2019). ANC provides an opportunity to improve the health of mothers and their babies (Barzeev et al., 2014).

Antenatal midwifery services must meet "10T" service standards, namely weighing and measuring height, measuring blood pressure, measuring mid-upper arm circumference (MUAC), measuring fundal uterine height, determining fetal location and calculating fetal heart rate (FHR), tetanus immunization, administration of $\mathrm{Fe}$ tablets, laboratory examinations, potential risk management, and counseling (Ministry of Health, 2010).

The performance of midwives in antenatal care can be seen through the achievement of $\mathrm{MCH}$ program indicators which include the first coverage of pregnant wo- men (K1), coverage of pregnant women's ANC visits (4 times), iron ( $\mathrm{Fe} 3$ ) and delivery assistance by health personnel (Ministry of Health, 2010). Based on the health profile of Samarinda City in 2017, the achievement of first ANC visit was 93.2\% while the coverage of ANC visit 4 times was reported to be at $83.8 \%$. This achievement has decreased when compared to that of 2016, first ANC visit at $98.2 \%$ and ANC visit 4 times at $94.4 \%$. The increase of MMR and the decrease of the coverage of ANC visit were related to the problem of midwifery performance that has not been optimal.

Performance is influenced by three variables, namely individual variables (knowledge, education, ability, skills, experience and demographic characteristics), organizational variables (resources, leadership, reward, structure and work design), and psychological variables (perception, attitude, personality, and motivation). These three variables influence the working attitude which ultimately affects the personal performance (Gibson et al., 2012).

Khavayet et al. (2018) study reveals that job satisfaction is influenced by working position, job security, salary and benefits, working environment conditions, relationships with colleagues, supervision, management policies, and personal relationships.

Therefore, this study aims to analyze the contextual influence of public health center and other factors that influence the performance of midwives in antenatal care services.

\footnotetext{
SUBJECTS AND METHOD

a. Study Design

This was an analytic observational study with a cross sectional design. It was conducted at 25 community health centers (puskesmas) in Samarinda, Kalimantan, Indonesia, from April to May 2019.
} 
Journal of Health Policy and Management (2019), 4(3): 150-160

https://doi.org/10.26911/thejhpm.2019.04.03.01

\section{b. Population and Sample}

The target population of this study was all public health center midwives in Samarinda, East Kalimantan. The sampling technique in this study was total sampling to get 180 midwives.

\section{c. Study Variables}

The dependent variable was performance of midwives. The independent variables were age, knowledge, tenure, training, workload, incentives, supervision, and motivation.

\section{d. Operational Definition of Study Variables}

Midwives performance was the ability of midwives to carry out their duties in ANC services according to the $10 \mathrm{~T}$ standard. The data collection was done using observation. The data were collected by questionnaire. The measurement scale was continuous, but for data analysis it was transformed into dichotomous.

Age was how old the subjects are at the time of the study was conducted. The data collection was conducted using a questionnaire. The data were collected by questionnaire. The measurement scale was continuous, but for data analysis it was transformed into dichotomous.

Knowledge was an intellectual ability and level of understanding, especially knowledge of midwives on the application of ANC services according to standards. The data collection was done using a questionnaire. The measurement scale was continuous, but for data analysis it was transformed into dichotomous.

Tenure was the length of time the midwife has passed since the first day of working to the year of the study was conducted. The data were collected by questionnaire. The measurement scale was continuous, but for data analysis it was transformed into dichotomous.

Training was the amount of additional education that midwives have participated in to increase their knowledge and skills related to ANC service. The data were collected by questionnaire. The measurement scale was continuous, but for data analysis it was transformed into dichotomous.

Workload was tasks that are given to midwives to be completed in a certain period of time involving additional tasks besides their job descriptions. The data were collected by questionnaire, resulting in continuous data, but for analysis it was transformed into dichotomous data.

Incentives mean the provision of benefits beyond the basic salary received by midwives from the results of service to the community. The data were collected by questionnaire. The measurement scale was continuous, but for data analysis it was transformed into dichotomous.

Supervision was a monitoring, evaluation and guidance visit conducted by the head of public health centers to the midwife regularly. The data were collected by questionnaire. The measurement scale was continuous, but for data analysis it was transformed into dichotomous.

Motivation is a work push that arises from within to do work in ANC services according to standards. The data were collected by questionnaire. The measurement scale was continuous, but for data analysis it was transformed into dichotomous.

\section{e. Data Analysis}

Continuous data of sample characteristic were described in $\mathrm{n}$, mean, $\mathrm{SD}$, minimum, and maximum. Categorical data were described in $\mathrm{n}$ and percent (\%). Bivariate analysis employed chi square test to determine the relationship between midwife performance and independent variables. Multivariate analysis employed multilevel multiple logistic regression analysis.

\section{f. Research Ethics}

Research ethics in this study include approval sheets, anonymity, confidentiality, and 
ethical feasibility. Ethical feasibility in this study came from the Health Research Ethics Committee of the UNS FK with numbers: 141 / UN27.06 / KEPK / 2019.

$\frac{\text { RESULTS }}{\text { 1. Sample Characteristics }}$

Table 1 shows the characteristics of sample.

Table 1. Samples characteristics (continuous Data)

\begin{tabular}{llcccc}
\hline \multicolumn{1}{c}{ Variables } & (n) & Mean & SD & Min. & Max. \\
\hline Age & 180 & 36.3 & 9.9 & 21 & 58 \\
Knowledge & 180 & 9.7 & 1.3 & 7 & 12 \\
Working period & 180 & 13.2 & 10.3 & 1 & 37 \\
Training & 180 & 2.1 & 1.5 & 0 & 6 \\
Workload & 180 & 13.7 & 1.6 & 10 & 19 \\
Supervision & 180 & 29.4 & 3.1 & 20 & 38 \\
Motivation & 180 & 45.3 & 3.7 & 35 & 56 \\
Performance & 180 & 19.4 & 0.9 & 17 & 20 \\
\hline
\end{tabular}

Table 2. Samples characteristics (categorical data)

\begin{tabular}{lcc}
\hline Characteristics & $\mathrm{N}$ & Percent (\%) \\
\hline Age & & \\
$\leq 45$ years & 139 & 72.2 \\
$>$ 45 years & 41 & 22.8 \\
Knowledge & & \\
Lacking & 42 & 23.3 \\
Good & 138 & 76.6 \\
Tenure & & \\
$<13$ years & 102 & 56.7 \\
$\geq 13$ years & 78 & 43.3 \\
Training & & \\
$<2$ training & 60 & 33.3 \\
$\geq 2$ training & 120 & 66.7 \\
Workload & & \\
Light & 87 & 48.3 \\
Heavy & 53 & 51.7 \\
Incentives & & \\
No & 93 & 44.4 \\
Supervision & 80 & 55.6 \\
No & 100 & 38.3 \\
Yes & & 61.7 \\
Motivation & 69 & \\
High & 111 & 47.2 \\
Performance & & 52.8 \\
Poor & 85 & 26.7 \\
Good & 95 & 73.3 \\
\hline B Bivariate Analysi
\end{tabular}

\section{Bivariate Analysis}

Table 3 shows the results of bivariate analysis of factors that influence the performance of midwives. Table 2 shows that age $\leq 45$ years $(\mathrm{OR}=2.53 ; \mathrm{p}=0.047)$, good knowledge (OR = 4.11; $\mathrm{p}<0.001)$, working period $>13$ years $(\mathrm{OR}=8.40 ; \mathrm{p}<0.001)$, training $\geq 2(\mathrm{OR}=6.48 ; \mathrm{p}<0.001)$, heavy workload $(\mathrm{OR}=0.49 ; \mathrm{p}=0.037)$, incentives $(\mathrm{OR}=11.50 ; \mathrm{p}<0.001)$, supervision $(\mathrm{OR}=$ $3.51 ; \mathrm{p}<0.001)$, and motivation $(\mathrm{OR}=5.09$ ; $\mathrm{p}<0.001)$ improve the performance of midwives statistically significant. 
Journal of Health Policy and Management (2019), 4(3): 150-160

https://doi.org/10.26911/thejhpm.2019.04.03.01

Table 3. The results of bivariate analysis

\begin{tabular}{|c|c|c|c|c|c|c|c|c|}
\hline \multirow{3}{*}{ Independent Variables } & \multicolumn{4}{|c|}{ Work performance } & \multirow{2}{*}{\multicolumn{2}{|c|}{ Total }} & \multirow{3}{*}{ OR } & \multirow{3}{*}{$\mathbf{p}$} \\
\hline & \multicolumn{2}{|c|}{ Poor } & \multicolumn{2}{|c|}{ Good } & & & & \\
\hline & $\mathbf{n}$ & $\%$ & $\mathbf{n}$ & $\%$ & $\mathbf{n}$ & $\%$ & & \\
\hline \multicolumn{9}{|l|}{ Age } \\
\hline$\leq 45$ years & 42 & 30.2 & 97 & 69.8 & 139 & 100 & \multirow{3}{*}{2.53} & \multirow{3}{*}{0.047} \\
\hline$>45$ years & 6 & 14.6 & 35 & 85.4 & 41 & 100 & & \\
\hline Knowledge & & & & & & & & \\
\hline Poor & 21 & 50.0 & 21 & 50.0 & 42 & 100 & \multirow{3}{*}{4.11} & \multirow{2}{*}{$<0.001$} \\
\hline Good & 27 & 19.6 & 111 & 80.4 & 138 & 100 & & \\
\hline \multicolumn{8}{|l|}{ Tenure } & \\
\hline$<13$ years & 42 & 41.2 & 60 & 58.8 & 102 & 100 & \multirow{2}{*}{8.40} & \multirow{2}{*}{$<0.001$} \\
\hline $\begin{array}{l}\geq 13 \text { years } \\
\text { Training }\end{array}$ & 6 & $7 \cdot 7$ & 72 & 92.3 & 78 & 100 & & \\
\hline$<2$ & 31 & 51.7 & 29 & 48.3 & 60 & 100 & \multirow{2}{*}{6.48} & \multirow{2}{*}{$<0.001$} \\
\hline $\begin{array}{l}\geq 2 \\
\text { Workload }\end{array}$ & 17 & 14.2 & 103 & 85.8 & 120 & 100 & & \\
\hline Light & 17 & 19.5 & 70 & 80.5 & 87 & 100 & \multirow{3}{*}{0.49} & \multirow[b]{2}{*}{0.037} \\
\hline Heavy & 31 & 33.3 & 62 & 66.7 & 93 & 100 & & \\
\hline \multicolumn{8}{|l|}{ Incentives } & \\
\hline No & 40 & 50.0 & 40 & 50.0 & 80 & 100 & \multirow{3}{*}{11.50} & \multirow[b]{2}{*}{$<0.001$} \\
\hline Yes & 8 & 8.0 & 92 & 92.0 & 100 & 100 & & \\
\hline \multicolumn{8}{|l|}{ Supervision } & \\
\hline No & 29 & 42.0 & 40 & 58.0 & 69 & 100 & \multirow{3}{*}{3.51} & \multirow[b]{2}{*}{$<0.001$} \\
\hline Yes & 19 & 17.1 & 92 & 82.9 & 111 & 100 & & \\
\hline \multicolumn{8}{|l|}{ Motivation } & \\
\hline Low & 36 & 42.2 & 49 & 57.6 & 85 & 100 & \multirow{2}{*}{5.09} & \multirow{2}{*}{$<0.001$} \\
\hline High & 12 & 12.6 & 83 & 87.4 & 95 & 100 & & \\
\hline
\end{tabular}

\section{Multilevel Analysis}

Table 4 shows the results of multivariate analysis. Midwives aged >45 years are less likely to have better performance than age $\leq 45$ years $(\mathrm{b}=-2.48$; 95\% $\mathrm{CI}=-4.53$ to $4.34 ; \mathrm{p}=0.018)$. Midwives who have good knowledge are more likely to have better performance than midwives who have less knowledge $(b=1.35 ; 95 \% \mathrm{CI}=0.38$ to 2.31 ; $\mathrm{p}=0.006)$. Midwives whose working age is $\geq 13$ years are more likely to have better performance than midwives who have $<13$ years of work $(b=1.89 ; 95 \% \mathrm{CI}=-0.07$ to 3.86; $\mathrm{p}=0.059)$. Midwives who had participated in the training were more likely to have better performance than midwives who had not yet received training $(b=1.30$;
95\% CI $=0.29$ to $2.30 ; \mathrm{p}=0.011$ ). Midwives who have a heavy workload are less likely to have better performance than midwives who have a light workload ( $b=-1.30 ; 95 \%$ $\mathrm{CI}=-2.27$ to $-0.34 ; \mathrm{p}=0.008$ ). Midwives who get incentives are more likely to have good performance than midwives who do not get incentives $(b=1.74 ; 95 \% \mathrm{CI}=0.30$ to $3.18 ; \mathrm{p}=0.018$ ). Supervision midwives from Puskesmas heads are more likely to have better performance than midwives who do not receive supervision $(b=1.12$; 95\% CI $=0.19$ to $2.05 ; \mathrm{p}=0.017)$. High motivated midwives are more likely to have better performance than low motivated midwives $(\mathrm{b}=1.42 ; 95 \% \mathrm{CI}=0.45$ to 2.38 ; $\mathrm{p}=0.004)$. 
Table 4. The results of multilevel multiple logistic regression

\begin{tabular}{lcccc}
\hline \multirow{2}{*}{ Independent Variable } & \multirow{2}{*}{ b } & \multicolumn{2}{c}{ CI (95\%) } & \multirow{2}{*}{ p } \\
\cline { 3 - 4 } Fixed Effect & & Lower Limit & Upper Limit & \\
Age ( $>$ 45 years) & -2.48 & -4.53 & -4.34 & 0.018 \\
Knowledge (Good) & 1.35 & 0.38 & 2.31 & 0.006 \\
Working period ( $\geq$ 13 years) & 1.89 & -0.07 & 3.86 & 0.059 \\
Training ( $\geq 2$ 2) & 1.30 & 0.29 & 2.30 & 0.011 \\
Workload (heavy) & -1.30 & -2.27 & -0.34 & 0.008 \\
Incentive (yes) & 1.74 & 0.30 & 3.18 & 0.018 \\
Supervision (yes) & 1.12 & 0.19 & 2.05 & 0.017 \\
Motivation (high) & 1.42 & 0.45 & 2.38 & 0.004 \\
Random Effect & & & & \\
Public health centers var (constant) & $<0.01$ & -3.05 & -0.77 & \\
N observation = 180 & & & & \\
Log likelihood = -58.63 & & & & \\
ICC =< $\%$ & & & & \\
\hline
\end{tabular}

\section{DISCUSSION}

\section{The effect of age on the midwives performance}

The result of the analysis shows that age has an influence on the performance of midwives and is statistically significant. Age $>45$ years has the potential to lower the performance.

Gusti et al. (2018) reported that age $\geq$ 27 years increased by 2.08 times good performance compared to age <27 years. Kotur and Anbazhagan (2014) stated that age influences employee's performance. The increase of the age tends to show better performance, but after the age of 45 years the performance decreases. Age $>45$ years, it naturally will make them weak, both psychologically and physically. This will affect the performance of employees in working.

Age $\leq 45$ years were considered to have high productivity when viewed physically and psychologically. At a certain age, people will experience changes in performance. Younger age is easier to provide feedback with a new approach. This shows that a young person is easier to give new input than the old ones (Wanma et al., 2018).

\section{The effect of knowledge on midwife performance}

The results of the analysis showed that knowledge had an influence on the performance of midwives and was statistically significant. Midwives who have good knowledge tend to show better performance than midwives who have poor knowledge.

Sharif et al. (2016) study shows that there is a relationship between knowledge, attitudes, and performance of nurses in hospitals in terms of hand washing. Health personnel who have good knowledge take a positive attitude in acting so that they can improve their performance.

Shakeri et al. (2018) which stated that there is a significant relationship between knowledge, attitudes, and clinical skills. The quality of the health care system is very dependent on the knowledge, attitudes, and skills of health workers. Knowledge influences attitudes and attitudes affecting skills and performance. Encouraging the knowledge and practice of midwives in antenatal care greatly helps reduce maternal morbidity and mortality (Elkhalifa and Kuppuswamy, 2014). 
Journal of Health Policy and Management (2019), 4(3): 150-160

https://doi.org/10.26911/thejhpm.2019.04.03.01

\section{The effect of tenure on the midwife performance}

The results of the analysis show that the working period has an influence on the performance of midwives and is statistically significant. Midwives with tenure $>13$ years tend to have better performance than midwives who have $<13$ years of work.

This study was in line with Francis (2015), which stated that there was an effect of working period on the job satisfaction. The longer employees spend time on work, the more satisfied they are and the more they can improve their performance.

A study by Olatunji and Mokuolu (2014) showed that the satisfaction and performance increase along with the increase of working period. Health personnel who have worked $>10$ years are more satisfied with their performance compared to health personnel who work $<10$ years. Experience in a job can reduce stress levels which then increase satisfaction and performance. New health personnel ( $<10$ years) have concerns, fatigue, frustration, and job dissatisfaction which ultimately affects their performance.

\section{The effect of training on the performance of midwives}

This study showed that the training had an influence on the performance of the midwife and was statistically significant. Midwives who had attended training $>2$ tend to have better performance than midwives who had not attended training.

Jayanti et al. (2017) stated that there was a positive effect of training on the performance of midwives. Performance-related training was the development and improvement of skills that had an impact on individual and team performance.

Midwife refresher training, especially the quality of training can affect the trust and practice of midwives. It allows health personnel to continue to practice the steps taken in maternal and infant health care so as to increase the confidence of midwives (Gobezayehu et al., 2014).

Training can affect the knowledge and attitudes of midwives. The longer information is stored in short-term memory with the help of repetition, the more likely it is to enter long-term memory so it is more permanent. The knowledge will be stored for a long time in memory if the repetition is done when needed (Mustamin, 2018).

\section{The effect of workload on the per- formance of midwives}

This study showed that the workload had an influence on the performance of midwives and was statistically significant.

The heavier the workload of midwives, the more they have the potential to reduce their performance.

The results of the study were in line with the results of Marfu'ah et al. (2016) which states that the higher the workload of midwives, the lower the performance shown. A heavy workload will cause various effects such as physical and mental fatigue, and other emotional reactions.

Asamani et al. (2016) reported that there was a correlation between the level of workload and the performance of health personnel. Heavy workloads tend to cause feelings of helplessness and fatigue which can reduce performance. Meanwhile, light workloads lead to a job satisfaction so that the performance can improve. The workload was also related to the work stress faced by midwives. Midwives who have a higher level of work status have lower job satisfaction so that their performance decreases (Talasaz et al., 2014).

\section{The effect of incentives on the performance of midwives}

The results of the analysis show that incentives have an influence on the performance of midwives and are statistically significant. Midwives who get incentives have better 
performance than midwives who do not get incentives.

The results of the study are supported by a study of Jayanti et al. (2017) which stated that there was a positive and indirect influence on incentives for midwife performance through motivational variables. Aninanya et al. (2016) stated that the provision of incentives can increase the motivation of health personnel in health centers in low-income areas in Ghana.

The incentives were designed to motivate and encourage health personnel to work better. The incentives provided in health services can be in the form of money or non-finance in accordance with the performance of health personnel as a form of appreciation and strong motivation to improve their performance (Abduljawad and Al-Assaf, 2011).

\section{The effect of supervision on midwives performance}

The result of the analysis showed that supervision had an influence on midwife performance and was statistically significant. Supervisory midwives from the public health center head have better performance compared to midwives who did not receive supervision.

Boseren et al. (2015) stated that there was a supervisory relationship with the performance of midwives $(\mathrm{p}=0.001)$. Bekru et al. (2017) reported that supervision increases 4.33 times job satisfaction. Good supervision makes health personnel love their work environment, improve efficiency, which in turn will increase job satisfaction and performance.

Emotional support can be obtained through supervision by providing opportunities for health personnel to explore, discover and examine their performance in a supportive environment. The process of emotional support can improve the quality of performance and performance satisfac- tion and reduce pressure (Circenis et al., 2015).

\section{The effect of motivation on midwife performance}

This study showed that motivation had an influence on the performance of midwives and was statistically significant. Midwives who have high motivation have better performance than low motivated midwives.

Wahidah et al. (2018) states that there was an effect of motivation on the performance of midwives. Ali et al. (2016) state that there is an effect of motivation on performance and job satisfaction. Motivation was the main element for improving performance and job satisfaction and can increase the ability of individuals and organizations.

Motivation was defined as internal and external driving forces that make individuals carry out an activity to achieve certain goals. Motivation can be in the form of reward, leadership style and language used by leaders in improving employee performance (Robescu and Iancu, 2016).

\section{The effect of the public health cen- ter contextual on midwives perfor- mance}

The results of the analysis show that the ICC value is $<1 \%$, which means that there is no contextual influence of the public health center on the performance of the midwife. The results of this study are not in line with the study of Gusti et al. (2018) which states that there is a contextual influence of the health center on the performance of midwives ( $\mathrm{ICC}=45.78 \%)$. This is due to the possibility that there are almost the same environment and work environment in each health center, so that the health center contextual role in this study does not affect the performance of the midwife.

\footnotetext{
AUTHOR CONTRIBUTION

Latifah Nur Rahmadani collected data, described the data, and wrote the article.
} 
Journal of Health Policy and Management (2019), 4(3): 150-160

https://doi.org/10.26911/thejhpm.2019.04.03.01

Uki Retno Budihastuti suggested for discussion. Eti Poncorini examined the conceptual framework and methodology.

\section{FUNDING AND SPONSORSHIP}

This study used the authors' independent costs.

\section{CONFLICT OF INTEREST}

There is no conflict of interest in this study.

\section{ACKNOWLEDGMENT}

We would like to thank community health centers and midwives for assistance in the data collecting.

\section{REFERENCE}

Abduljawad A, Al-Assaf AF (2011). Incentives for better performance in health care. Sultan Qaboos University Medical Journal. 11(2): 201-6. http://www.ncbi.nlm.nih.gov/pubmed/21969891\%oAhttp://www.pubmedcentra l.nih.gov/articlerender.fcgi?artid=PM C3121024

Ali A, Bin LZ, Piang HJ, Ali Z (2017). The impact of motivation on the employee performance and job satisfaction in IT park (software house) sector of Peshawar, Pakistan. International Journal of Academic Research in Business and Social Sciences. 6(9): 297-310. doi: 10.6007/ijarbss/v6-i9/2311.

Aninanya GA, Howard N, Williams JE, (2016). Can performance-based incentives improve motivation of nurses and midwives in primary facilities in northern Ghana? A quasi-experimental study. Global Health Action. 9(1): 1-10. doi: 10.3402/GHA.V9.32404.

Asamani JA, Amertil NP, Chebere M (2016). The influence of workload levels on performance in a rural hospital. British Journal of Health Care Management. 21(12): 577-586. doi: 10.- 12968/bjhc.2015.21.12.577.

Barzeev S, Barclay L, Kruske S, Kildea S (2014). Factors affecting the quality of antenatal care provided to remote dwelling Aboriginal women in northern Australia. Midwifery. 30(3): 289-296. doi:10.1016/j.midw.2013.04.009.

Bekru ET, Cherie A, Anjulo AA (2017). Job satisfaction and determinant factors among midwives working at health facilities in Addis Ababa city, Ethiopia. Plos One. 12(2): 1-16. doi: 10.1371/journal.pone.0172397.

Boseren S, Noor NB, Rantetampang AL (2015). Determinants affecting performance of village midwife in biak numfor regency. international journal of sciences: basic and applied research. 24(6): 419-425. http://gssrr.org/index.php?journal=JournalOfBasicAndAppli ed.

Circenis K, Jeremejeva J, Millere I, Deklava L, Paparde A, Sudraba V (2015). Supervision in nursing: Latvian Sample Study. Procedia - Social and Behavioral Sciences. 205(2015): 86-91. doi: 10.1016/j.sbspro.2015.09.023.

Samarinda Health Office (2018). Profil Kesehatan Kota Samarinda Tahun 2017 (Samarinda City Health Profile 2017). Samarinda Health Office: Samarinda

Douglas DB, Waziry R, Mccarthy EP, Tadesse AW, Feyssa MD, Kawooya M, Sudfeld CR (2019). Meeting the world health organization maternal antenatal care. The Journal of Pediatrics. 2(32): 1-7. doi: 10.1016/j.jpeds.2019.02.032.

Elkhalifa AE, Kuppuswamy SB (2014). Evaluation of midwifery knowledge on antenatal care in omdurman maternity hospital Sudan. International Journal of Health Sciences. 2(2): 127-142. https://www.researchgate.net/publicat ion/266143906

Francis UC (2015). Influence of gender, age 
and job tenure on job satisfaction of medical and non-medical employees of a university teaching hospital in lagos, Nigeria. African Journal for the Pshychological Study of Sicial Issue. 18(3): 96-107. https://www.ajol.info/index.php/ajpssi/article/view/137026

Gibson JL, Ivancevich JM, Donelly JH (2012). Organisasi, Perilaku, Struktur, dan Proses. Jakarta: Binaputra Aksara.

Gobezayehu AG, Mohammed H, Michelle M (2014). Knowledge and skills retention among frontline health workers: community maternal and newborn health training in rural Ethiopia. Journal of Midwifery and Women's Health. 59(1): 21-31. doi: 10.1111/jmwh.12146.

Gusti TE, Tamtomo D, Murti B (2019). Determinants of midwife performance on antenatal care in Surakarta and Karanganyar, Central Java. Journal of Health Policy and Management. 3(1): 11-19. https://doi.org/10.26911/thejhpm.2018.03.01.02.

Jayanti ND, Tamtomo D, Sulaeman ES (2014). Path in analysis on the effects of motivation and other factors on midwives performance of preeclampsia management Malang, East Java. Journal of Health Policy and Management. 2(2): 137-146. https://doi.org/10.26911/thejhpm.2017.02.02.05

Ministry of Health of Indonesia (2010). Pedoman pelayanan antenatal terpadu (Integrated antenatal care guidelines). Jakarta

Khavayet F, Tahery N, Alizadeh AM, Tabnak A (2017). A Survey of job satisfaction among midwives working in hospitals. Journal of Midwifery and Reproductive Health. 6(1): 1186-1192. doi: 10.22038/jmrh.2017.9943.

Kotur BR, Anbazhagan S (2014). Influence of age and gender on the performance. Journal of Business and Management.
16(5): 97-103. www.iosrjournals.org

Marfu'ah S, Tamtomo D, Suryono A (2016). Effect of psychological factors and workload on midwife performance in the integrated antenatal care in Pati, Central Java. Journal of Maternal and Child Health. 1(3): 138-145. https://doi.org/10.26911/thejmch.2016.01.03.01 .

Mustamin, Amiruddin R, Palutturi S, Rahman SA, Risnah (2018). Training effect to the knowledge and skills of midwives in maternity health services at primary health care. International Journal of Community Medicine and Public Health. 5(11): 4651-4655. http://dx.doi.org/10.18203/2394-6040.ijcmph20184248

Olatunji SO, Mokuolu BO (2014). The influence of sex, marital status, and tenure of service on job stress, and job satisfaction of health workers in a nigerian Federal Health Institution. African Journal. 8(1): 126-133. http://dx.doi.org/10.4314/afrrev.v8i1.10

Robescu O, Iancu AG (2016). The effects of motivation on employees performance in organizations. Valahian Journal of Economic Studies. 7(2): 49-56. doi: 10.1515/vjes-2016-0006.

Shakeri K, Khoshknab MF, Khankeh M, Hosseini M, Heidari M (2018). Knowledge, attitude, and clinical skill of emergency medical technicians from Tehran emergency center in trauma exposure. International Journal of Critical Illness Injury and Science. 8(4): 188-193. doi: 10.4103/IJCIIS.IJCIIS_33_18.

Sharif A, Arbabisarjou A, Balouchi A, Ahmadidarrehsima S, Haddad H, Kashani (2016). Knowledge, attitude, and performance of nurses toward hand hygiene in hospitals. Global Journal Health Science. 8(8): 57-65. doi: 
Journal of Health Policy and Management (2019), 4(3): 150-160

https://doi.org/10.26911/thejhpm.2019.04.03.01

10.5539/gjhs.v8n8p57.

Talasaz, ZH, Saadoldin SN, Shakeri, MT (2014). The relationship between job satisfaction and job performance among midwives working in healthcare centers of Mashhad, Iran. Journal of Midwifery and Reproductive Health 2(3): 157-164. doi: 10.22038/jmrh.2014.2623

Wahidah N, Sulaeman ES, Budihastuti UR (2019). Determinants of midwife performance in lactation management in Surakarta and Karanganyar, Central Java. Journal of Health Policy and Ma- nagement. 3(1): 26-33. doi: 10.26911/thejhpm.2018.03.01.04.

Wanma AI, Ruru Y, Rantetampang AL, Mallongi A (2018). The factors influence with midwife performance to antenatal care at public health centre Wania Sub Province Mimika. International Journal of Science and Healthcare Research. 3(3): 15-26. http://ijshr.com/IJSHR_Vol.3_Issue.3_July2018/IJSHRoo4.pdf

WHO (2018). Maternal Mortality. https://www.who.int/newsroom/fact-sheets/detail/maternal-mortality. 